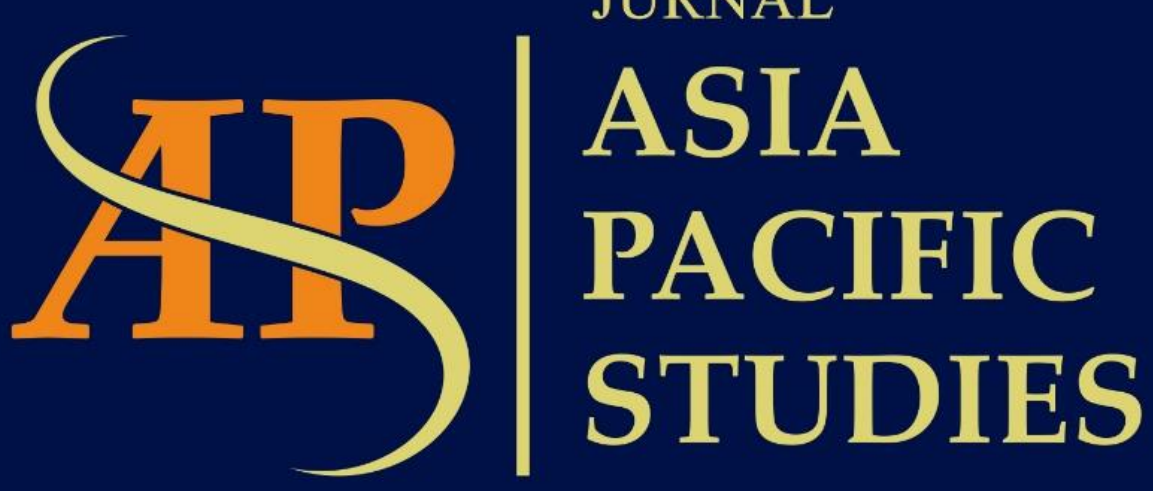

Journal of International Relations Study Program Faculty of Social and Political Sciences Universitas Kristen Indonesia

Volume I | Number 2 | July - December 2017 


\title{
CAN FEMINISM BE CONSIDERED A MAINSTREAM THEORY OF INTERNATIONAL RELATIONS?
}

\author{
Mita Yesyca \\ Hubungan Internasional, Fakultas Ilmu Sosial Ilmu Politik, Universitas Kristen Indonesia, \\ Jl. Mayjen Sutoyo No. 2, Jakarta Timur, 13630, Indonesia \\ mita.yesyca@uki.ac.id
}

\begin{abstract}
$\underline{\text { Abstract }}$
The growth of Feminism which has given rise to a new study in the International Relations (IR) field is worth to follow. Not only since it is able to contribute to the academic discipline of IR in theoretically challenging the traditional approach to understand the world politics, but also since it is able to contribute practically because of its nature as a socio-political movement. Nevertheless, in the IR itself there is always a question concerning the possibility of Feminism to be considered a mainstream theory. This article tries to discuss the theoretical contribution of, as well as some issues followed, the development of Feminism in the study of international relations all this time. It finally argues that Feminism can be considered a mainstream theory of international relations so long as there are conversations between traditional theories of international relations and feminists theories of international relations.
\end{abstract}

Keywords: Feminism, International Relations, mainstream theory

\begin{abstract}
Abstrak
Perkembangan Feminisme yang telah melahirkan suatu kajian baru dalam ilmu Hubungan Internasional (HI) layak untuk disimak. Tak hanya karena ia mampu menyumbang secara teoritis kepada disipilin ilmu HI dalam menantang pendekatan tradisional untuk memahami politik dunia, tetapi juga karena ia mampu menyumbang secara praktis mengingat bahwa sejatinya ia merupakan sebuah gerakan sosial-politis. Meski demikian, dalam HI sendiri selalu ada pertanyaan mengenai peluang Feminisme untuk diterima sebagai sebuah teori yang lazim. Tulisan ini mencoba mendiskusikan sumbangan teoritis dari, sekaligus perdebatan-perdebatan yang mengikuti, perkembangan Feminisme dalam kajian hubungan internasional selama ini. Argumen yang dibangun pada akhirnya ialah bahwa Feminisme dapat dianggap sebagai sebuah teori tentang hubungan internasional yang lazim sepanjang terdapat percakapan antara teori tentang hubungan internasional tradisional dan teori feminis tentang hubungan internasional.
\end{abstract}

Kata kunci: Feminisme, Hubungan Internasional, teori mainstream 


\section{Background}

The relationship between Feminism and International Relations-the discipline which becomes an umbrella for many theories of international relations - is never easy. However, looking upon International Relations as an unfinished inter-related and interconnected scholarly journey needing to be reviewed periodically, I argue that Feminism can be considered a mainstream theory of international relations. What I mean by mainstream is in a sense of ceasing to be seen as irrelevant or shocking; so long as there are conversations between traditional theories of international relations and feminist theories of international relations. Such conversations will provide the chance for the academic world citizens to understand and engage unlimited possibilities of change and progress to a more just and fairer social world. In addition, they will also provide feminists with the possibility of transgressing the boundaries set by traditional theories of international relations.

As generally accepted by academics in the field, the phrase 'International Relations' refers to an academic discipline; while 'international relations' refers to the practice of world politics, which by some people, e.g. Kenneth Waltz, Robert Keohane, and Alexander Wendt, refer (almost exclusively) to interstate interactions. From this understanding, 'mainstream theories of international relations' addressed in this essay refers to the widely-shared theory or thought about world politics accross people involved in the field (e.g. scholars, policymakers, citizens, Non-Governmental Organisations, International Organisations). Meanwhile, what is no less important, reviewing or revisiting how its body of scholarship has grown must serve as an attempt to provide such directory of those rich and keep growing number of its body member. This effort, I argue, should not be treated as a way to simplify or make generalised claims concerning what the "International Relations" is. The great range and scope of the contributions of thought will definitely be useful to inform groups of research on new questions and problems in today's international relations as well as in the future to come.

Looking to the evolvement of International Relations, like many other disciplines, one can easily find that the study has evolved around contemporary events or issues as the evidence on which certain theoretical ideas are built. The traditions has it, that studying International Relations means every student must learn to recognise the great debates which, some people argued, have contributed in constructing International Relations the way it becomes renowned today (Schmidt 2014). Nonetheless, one cannot close eyes towards the benefits International Relations has gained from dialogues with theories from various thinkers, "from a series of distinct traditions and sub-traditions, who might sit rather uncomfortably together" in understanding international phenomena (Edkins and Vaughan-Williams 2009, 1). They, indeed, have resulted wider array of approaches than decades ago, in order to explain, understand, and improve the international affairs. Without trying to simplify the broad study of international relations, here I propose a starting point to discuss about the relations between Feminism and Relations; that is my brief reading of International Relations development during the past decades. In this way, I think the next discussion on the vital contribution of Feminism to International Relations will be easier to follow.

The origins of International Relations tried to explain the events of international politics; how the behavior of the state-actors determined by a structure in the international system, that is either bipolar or multipolar one (Sullivan 2001, 4). Then, the idea that distinct objects or entities relate to each other in various ways was challenged by another idea that the world itself is of interconnectedness or being-with. Under this approach, the world is viewed to be made up by no distinct objects; whether states, individuals or anything else. Or in other words, there is no pre-set international structure and the structure itself is possible to change. This view leads to a very different figuration of the international, enabling the thinking of relationality and being in a way not permitted by language; a way that does not start with the 'one' (Edkins and 
Vaughan-Williams 2009, 2). Adopting this approach means broadening the scope of IR's concern, away from states and relationships between states to an interest in what might be meant by inter-relations in the first place, at whatever 'level' of social organisation (Edkins and Vaughan-Williams 2009, 3).

Approaching international relations as interconnected, interrelated phenomena also means admitting that there is undeniable connection between the international affairs being studied and the students of the social facts. It does imply that every individual cannot leave their social positions and values, meaning particular structure can take place in the individual's realm of thought through language; with no exception to all human. Such structure constructed by knowledge, recognised through language (or 'discourse'). Humans' positions and values influence the way the world is viewed and what they take to be the 'truth' of the world. The international affairs are also full with social meanings, interpretations, ideologies and discourses - which, in turn, bring attention to the importance of the international relations study's ideational dimension. This view is shared by Chyntia Weber, who sees International Relations as "an ensemble of stories" told about the world it studies, which is the world of international politics. Studying International Relations theory as a site of cultural practice means being attentive to how IR theory makes sense of the world of international politics (Weber 2009, 4).

To further discuss the dialogue between Feminism and International Relations, the next section of the article will be divided into four parts: The first section briefly discusses the origins of Feminism and what makes it important in understanding international relations; the second section discusses the problem raised when feminists try to make International Relations (to be referred to as 'IR') as their "home", how traditional theories of international relations - which have settled first — sets boundaries that might make it, in Tickner and Sjoberg's (2011) words, an "inhospitable home" for Feminism; the third section discusses whether there is a possibility for Feminism to be considered a mainstream theory of international relations; and finally, I will draw conclusion from the previous parts which leads to my answer for the question above.

\section{Feminism and Its Significant Contributions: The Concept of Gender}

The origins of Feminism itself can be traced back to the work of Mary Wollstonecraft, in which she argued that women required education to grant them freedom, an autonomy from men (Wollstonecraft 1792, 105). Today's Feminism is still a socio-political movement interested primarily in women's rights; but as a scholarly journey, its approach is not only useful to understand more about women but also the world in general. It is because feminist scholars suggested distinction between "sex", or biological maleness and femaleness, and "gender", which is social meaning attached to the shape of our bodies (Shepherd 2010, 4); masculinities are associated with maleness and femininities with femaleness. Feminists argue that gender differences also associated with power relations existed in almost every area of social and political life (Tickner and Sjoberg 2011, 4). Analysing gender opens up multiple expressions of inequality in the society which once were taken for granted. Gender differences entail hierarchical relations, for example in the diversity of women's lives themselves and not only in the hierarchical relations between one universal category of 'men' and 'women' (Peterson 1992, 195).

People usually categorise many strands of feminist theory based on the way they identify the root of oppressions and the way to engage as well as to transform it. Each of the strands may give impacts to the study of international relations differently. However, Edkins dan Vaughan-Williams argued that categorisation is problematic. According to them, which I am in line with, categorisation has risk of foisting a shapeliness or coherence where matters are often far messier (Edkins and Vaughan-Williams 2009, 5). In this section, I will focus explicitly 
on what I consider most important in the contemporary feminist thinking about international politics. My point here is to show the vital contribution of Feminism in uncovering the invisible aspects of international relations. While I acknowledge that within Feminism there is also a large body of thoughts, it is possible to pinpoint the key contribution of Feminism to IR considering the last development of international relations scholarship and its focus on the ideational dimension. Feminism's plural horizons started with its understanding on the concept of gender.

The concept highlights the social meaning associated with the shapes of humans' bodies as already mentioned before. Furthermore, this social meaning is surprisingly able to play role in prioritising certain features, issues or processes of social world. The meaning itself is "socially constructed, producing subjective identities" through which people see and know the world (Weber 2009, 103). To clarify, it is clearer to think of 'gender' as a noun (i.e. an identity), a verb (i.e. a way to look at the world), and a logic, which is produced by and productive of the ways in which all people understand and perform world politics - or in Shepherd's words, 'global politics' (Shepherd 2010, 5). Consequently, international relations is never neutral; but profoundly gendered. Feminist theories of IR, thus, are able to show and provide understandings on how the experience of women and others; who have been marginalized and are reflected in international relations. Using the concept of gender, IR scholarship is not as narrow as it once used to be: implicitly assuming a masculinist (i.e. privileging the masculine) viewpoint of international relations. This does not mean that only women are capable of seeing the world through a feminist or gendered lens, since using the lens is politically and not biologically grounded.

Feminists claim that gender manifests in the real material structures and institutions (e.g. the state and the family) and the way people understand and perform everyday lives. This will sound like a paradox, but Feminists make a "theory" of gender by not making a theory; they reveal how gender operates by reflecting on what already exists in the social reality, including world politics. That is their "theory" of international relations. As Laura J. Shepherd said that we "cannot ignore (or abstract) the ways that gender informs and affects the practices of world politics", and therefore it means, we have to pay attention to "the narratives about the body and representations of the body function, both male and female" in world politics (Shepherd 2010, $5-7)$.

\section{Boundaries Set by Traditional Theories Make IR an "Inhospitable Home" for Feminism}

Theories that "do not take account of this gender hierarchy are partial because of their neglect of it" (Tickner and Sjoberg 2011, 11). Feminists argue that "if knowledge claims are necessarily grounded in lived experience, not some transcendent reality, then elite male experience cannot be used to ground claims about human social reality; to do so distorts our knowledge of that reality" (Peterson 1992, 195). Nevertheless, in Cynthia Enloe's words, "making feminist sense" in IR is indeed a big task, for it interrogates beyond what are traditionally understood as the proper research questions of IR — one thing which I think often makes Feminism remain in the margin of IR. What makes a research concern "proper" can be traced back to the origins of the discipline, of which concerns were on the horrific impacts of war. Usually referring to the impacts of the Great War in 1914-18, the study grew out of the desire to ensure that there would be no more 'lost generations' (Steans et al. 2010, 1).

The developments of international relations after the Cold War seem to be far reaching and are unpredictable for traditional IR. We find that modern technologies and media communication have made it possible for people to get connected to each other in a way that we could not imagine a few decades ago. The boundary of the nation-states seems to remain 
only on the map. In reality? People, capital, money, information, and almost everything which once could not move around freely, can now move around easily as a result of developments in technology. Those developments indeed raise new issues in international relations.

The understanding of world politics which once was stable, is also challenged and needs to be rethought at present. A professor in a university may say the crucial problem in international relations is the interstate politics and therefore we need to understand state's behaviour. Robert $\mathrm{O}$. Keohane endorsed feminist standpoint theories for the potentials of giving richer formulation to neoliberal institutionalism (Keohane 1989, 250). At the same time, a business man who runs a multinational enterprise may say what matters most in international relations is connectivity, so that there can be one-single market, as Tony Fernandes, the CEO of AirAsia, disscussed it in APEC CEO Summit 2013 (APEC CEO Summit 2013). In another part of the world, a woman migrant domestic labour may not know much about the world politics, but may be very concerned about domestic employment opportunities in other country - no matter how risky the jobs as reflected in an interview with a woman migrant domestic labour (in Yesyca 2013, 187). The last two may seem irrelevant for traditional international relations theorists; but both of them raise new issues in international relations and both of them are connected to world politics "empirically". The double quote-marks here is used intentionally, since there is a difference in understanding what counts as empirical for traditional IR theorists and feminists. It will be discussed later in the next part of the article. They bring about new questions, not to the demand of the absence of war anymore; some of them are about the nature of power (Peterson 1992, 186).

Traditional theories of international relations do not speak much about individuals outside the concept of nation-states as well (Shepherd 2010,6). That fact reveals the inadequacy of analysing world politics through state-centric theories; whilst empirically who can act and become subject in the world politics are not only the states. Through the feminist perspective, we can see actors who were once invisible: individuals act in the stage too, men and women, not as 'nation' feature and not in the character of 'state' either. Also through the feminist perspective, which share the same spirit as post-positivists, we can see that the capacity to act of those individuals are different one another in the contingent and contextual ways: specific women had more capacity than other women and specific men lack of capacity compared to other men. This means that there is not just one "gendered" experience in the world politics, because 'genders are lived and performed differently and in different contexts' (Tickner and Sjoberg 2011, 4).

If Feminism does bring many productive insights in the study of international relations, what happened then to International Relations? Considering what we have discussed before, it is understandable if later there is a desire for theoretical transformations in IR. It is true that what happened in the international stage later sparked new interests of the IR scholars; but unfortunately, while the contemporary development of international relations has changed so much that raises deeper questions from what scholars were concerned about earlier, the focus on the inter-state relations remains dominant in the study of international relations until todayespecially in political science departments in the United States (Steans 2010, 238; Tickner and Sjoberg 2011, 11; Reus-Smit 2012, 532).

Some academics agree to reexamine, but not to replace or rewrite the ontologies of traditional IR: nation-states and their behaviour. Ontology refers to what can be said to exist, or the most important things, in the international relations (Jarvis 2002, 3). It is not surprising in the feminist perpective as there will be "distortions of androcentrism in privileging ways of knowing that are partial" (Peterson 1992, 195). The fact that international relations is also derived exclusively from male experience, as it is constructed under patriarchal relations, has made IR an "inhospitable home" for Feminism. 
Another boundary set by traditional IR is in term of epistemological consideration. Epistemology refers to how can we identify and understand the most important things in the international relations (Yosef Lapid in Jarvis 2002, 5). International Relations which was born later, after various modern sciences were born, was also heavily influenced by the 'Enlightenment project' that challenged tradition and religious doctrine in European history (Steans et al. 2010, 134). The Enlightenment thinkers promoted human's capacity for reasoning. Being in the same track, traditional theorists of International Relations are also committed to scientific, logical and rational forms of knowledge. As a result, it sets boundary for feminists to contribute in IR by assuming gender as a settled or essential feature of men and women, so that it can be identified as a variable which might be relevant in establishing 'causality laws' in international relations (Keohane, in Steans et al. 2010, 158). Such "placement" need to break down, because this act of "managing" the contributions of Feminism reveals more about the priorities and assumptions of the traditional IR theorists whose privileged positions are being questions. Here lies the problematic issue for feminists in IR, where the interests, values, and dominant power relations is legitimate or allowed to "silence the voices in the feminists' literature, instead of drawing our attention to its many voices" (Weber 1994, 348). This way, the traditional theories of international relations are successfully preserved and protected.

\section{Considering IR as A Scholarly Journey: The Need of Gender Mainstreaming in IR}

Considering the differences of ontology end epistemology used by traditional theorists of international relations and feminists, it makes sense that Feminism seems shocking when it enters the area of IR. Their productive insights will remain in vain, if IR scholars and practitioners insist on seeing them as irrelevant and not "scientific" enough. Where is the meeting point so that scholars and practitioners can see them relevant and useful for international relations study? I argue one should start by considering IR a scholarly journey of a social science.

The ideas of 'social' derives from the Latin socius, which originally meant friend or companion (Plummer 2010, 19). According to Plummer, it is later developed to mean a cluster of human associations and communities that mediate human experience. In a moment of history, the study of the social gave birth to IR as a discipline to study interstate war. Later we have seen that IR developed along with the context behind, and currently the main focus of the study is state and its behaviour. As one of the social sciences, IR scholars must accept the fact that what they are studying consists of living subjects who have diverse values. Even for traditional international relations theorists who insist on focusing their study on states and their behavior; they cannot deny the fact that state itself consists of living individuals. The study of international relations, therefore, should be developed as a 'living discipline from a living conversations', not as a final destination.

The term 'living discipline from living conversations' is first used by Sandra Harding to describe the development of feminist IR (in Tickner and Sjoberg 2011, 224). I put emphasis on 'living' because of the important dynamics nature of a discipline. The activities of ascertaining, testing, which committed to scientific inquiry to discover the 'law' of the social, also shall be admitted vulnerable to bias and discrimination on the diversity of the subjects in the 'social'. Again, according to Plummer, the word 'society' now comes to capture the idea of people functioning together in associations outside the workings of the state. So I prefer the word 'social' to 'society' here, to reaffirm that IR is one of social sciences; even though for some scholars what can be said exists in international relations is 'state', but that 'state' does consist of individuals who have diverse values. 
Taking individuals into account has been proven to bring more understanding to their analysis of state and its behaviour - as now more and more traditional international relations theorists adopt intersubjective approach (Rosenau 2002, 194; Steans 2010, 246). Feminists should push and persuade scholars in the centre stage of IR theory to take gender into account, since it also does matter in understanding state and its behaviour; but not in the sense of discovering 'general law'. Such "discovered" law can easily be exploited to justify the acts of certain individuals in the social who are dominant.

As a social science, IR also has to concern itself with the status of knowledge. Traditional international relations theorists argue that it is possible to understand the world objectively and try to discover the 'laws' that govern relations between states as modern sciences, like physics, strive to establish the laws of nature (Steans et al. 2010, 232). While it seems a good idea; later IR scholars, and also other social scientists, find that humans are much more complex than nature - this is evidenced by the debates brought by post-positivists. We cannot be neutral when we are looking at (or evaluating) ourselves, that is exactly what happens in the social sciences. To find one general formula for inter-state relations somehow is naive or crude (Reus-smit 2012, 536-537). Feminists see it probematic in the way that ideas and opinions that are thought to be normal, as they shared by most people, are actually the manifestation of power relations in the construction of knowledge (Jarvis 2002, 6).

Rethinking those things that were once considered 'settled' is troubling for traditional international relations theorists, but significant. It does provide chances for voices which once are 'silenced'. Therefore, Feminism is not trying to be mainstream in that way: by silencing various voices. The ideas and opinions that feminists propose to be widely accepted are the facts that there are unfair practices in the form of gender inequality and they are inherently reproduced in various ways in the world politics.

The task to complete is then to make IR a hospitable home for Feminism. I argue that it is possible for Feminism to be considered as a mainstream theory of international relations, so long as there are conversations between traditional theories of international relations and feminist theories of international relations. Such conversations will provide feminists with the possibility of transgressing the boundaries set by traditional theories of international relations. Successful conversations will result on the two conditions followed. First, there is a mutual understanding for what counts as 'empirical' between traditional international relations theorists and feminists. Second, the concept of 'gender' becomes so familiar that it helps people involved in this field to reconstruct the practice, policies, and the science of international relations into more gender-sensitive ones. In other words, it will need more and more feminists' works in international relations; not only as scholars through good researches, but also as practitioners through practice and policies. The rest of this article will echo the works of feminists IR who have tried to build conversations before, in order to make the concept of 'gender' more familiar (e.g. Peterson 1992; Wibben 2004; Shepherd 2010; Tickner and Sjoberg 2011; Soetjipto and Trimayuni 2013).

There should be more conversations between traditional international relations theorists in the centre and feminist international relations theorists in the margin of IR. It is not only in IR actually; engaging in conversations has been one of the characteristics of Feminism. Having large body of thoughts, feminists consider dialogue as one of the most appropriate ways to serve its normative concern: that gender hierarchy is inherently unjust (Tickner and Sjoberg 2011, 11). Therefore, the conversations in IR itself are not without purpose; it is fundamental for feminists, who are concerned about the relationship between positionality and knowledge, and also their political implications in theorising, analysing, and practicing international relations (Tickner and Sjoberg 2011,7) more than traditional IR theorists do. Conversations through articles, books, conferences, and other research products can bring attention to Feminism more 
than just a glance in passing - because it seems irrelevant or, worse, scary for scholars in the centre who think that it will bring IR to an end.

The boundaries set by traditional theories of international relations are socially constructed. As social constructions, they can be deconstructed, disrupted and transgressed (Peterson 1992, 183). The contemporary developments of international relations empirically have destabilised these boundaries. To further transgress them so that Feminism can cease to be shocking or irrelevant for international relations scholarship, there should be more conversations intersecting with the traditional theories of international relations. This optimistic view of mine - that Feminist theories of international relations can be widely accepted by scholars in this field, especially them who are in the centre-comes from finding the same ground for feminists and traditional international relations theorists to stand and make conversations.

Traditional international relations theorists look at IR as a science and attempt to establish 'widespread agreements among observers about the nature of what they study' until 'new findings refute them and observers flock to the new findings and form a consensual interpretation of them' (Rosenau 2002, 195). According to them, scholars as 'scientists aspire to broadening support for their interpretations' (Rosenau 2002, 195). From what Rosenau said, I think traditional international relations theorists actually already admit the diversity of values owned by individuals. What needs to be discussed further and shared by both of them is a common understanding on the concept of 'power'.

IR scholars in the centre should consider that some 'scientists' cannot get support as much as other scientists can. To understand this, a broader concept of power is needed: the one that manifests in discourse. This is totally different from the concept of power brought by traditional IR theorists. Discursive power determines what counts as "empirical", because it influences us in seeing realities, understanding causes, and predicting outcomes (Tickner and Sjoberg 2011, 11). This kind of power manifests in the way feminists face stunted conversations when they try to critique the study of international relations (Peterson 1992, 198). For feminists, the power is called 'gender'. This new understanding of power, the concept of gender, needs to be familiarised. If current mainstream IR theorists can accept it, this exactly will rewrite IR theoretically and practically.

\section{Conclusions}

From the discussion before, we can see that traditional ontology and epistemology of IR has set boundaries for Feminism to make it as a "home". Nevertheless, productive insight from feminists leads me to argue that their "theory" of international relations should not stay in the margin. But it will not happen anyway, if IR scholars and practitioners insist on seeing their theories as irrelevant and not "scientific". The meeting point for both of feminists and traditional IR scholars is in looking IR as a scholarly journey of social science. The importance of emphasising the social is the fact that what we study here is living subjects, who have diverse values which make the study prone to bias and discrimination.

I argue that Feminism can be considered a mainstream theory of international relations so long as there are conversations between traditional theories of international relations and feminists theories of international relations. The shared ground to start conversations is from the development of traditional IR theorists, who have now adopted the intersubjective approach. Further discussion is needed about the concept of power, which operates in the meaning construction of the practice of world politics. This discursive power, feminists suggested, is the one called 'gender'. If current mainstream IR theorists can accept it, this will rewrite IR theoretically and practically. By promoting the gender issues in IR, Feminism enrich it by opening up new spaces for rethinking and reassert the responsibility for practice and policies 
we made in the world politics. It echoes the commitment brought by IR when it was first constituted: "to bringing research and reflection to bear on fundamental international political problems, and generating ideas that might inform debate with the public sphere" (Reus-smit 2012, 533). Would it not mean handicapping IR theoretically and practically, if we limit feminists' contributions? Closing eyes to the way gender manifests in international relations is more harmful than allowing feminists to rewrite IR. 


\section{REFERENCES}

\section{Books}

Edkins, Jenny, and Nick Vaughan-Williams. 2009. "Introduction." In Critical Theories and International Relations, edited by Jenny Edkins and Nick Vaughan-Williams, 1-6. Oxon: Routledge.

Enloe, Cynthia. 2014. "Scrubbing the Globalized Tub: Domestic Servants in World Politics." In Bananas, Beaches and Bases: Making Feminist Sense of International Politics, 305342. Second Edition. California: University of California Press.

Jarvis, Darryl S. L. 2002. "Toward an Understanding of the Third Debate: International Relations in the New Millenium." In International Relations and the Third Debate: Postmodernism and Its Critics, edited by Darryl S. L. Jarvis, 1-13. Connecticut: Praeger.

Plummer, Ken. 2010. Sociology: the basics. New York: Routledge.

Rosenau, James N. 2002. "Confessions of a Pre-Postmodernist: Or Can an Old-Timer Change Course?" In International Relations and the Third Debate: Postmodernism and Its Critics, edited by Darryl S. L. Jarvis, 191-197. Connecticut: Praeger.

Shepherd, Laura J. 2010. "Sex or Gender? Bodies in World Politics and Why Gender Matters." In Gender Matters in Global Politics: A feminist introduction to International Relations, edited by Laura J. Shepherd, 3-16. New York: Routledge.

Soetjipto, Ani. 2013. "Gender, Feminisme, dan Hubungan Internasional [Gender, Feminism, and International Relations]." In Gender dan Hubungan Internasional [Gender and International Relations], edited by Ani Soetjipto and Pande Trimayuni, 1-31. Yogyakarta: Jalasutra.

Steans, J., L. Pettiford, T. Diez and I. El-Anis. 2010. An Introduction to International Relations Theory: Perspectives and Themes. Essex: Pearson Education.

Sullivan, Michael P. 2001. Theories of International Relations: Transition vs. Persistence. New York: Palgrave.

Tickner, J. Ann and Laura Sjoberg. 2011. Feminism and International Relations: Conversations about the past, present and future. New York: Routledge.

Weber, Cynthia. 2009. International Relations Theory: A Critical Introduction. Edisi Ketiga. Oxon: Routledge.

Wollstonecraft, Mary. 2004 [1792]. A Vindication of the Rights of Women. London: Penguin Books.

Yesyca, Mita. 2013. "Peningkatan Arus Migrasi TKW-PRT ke PEA [The Increasing Migration Flow of Women Domestic Labour to United Arab Emirates].” In Gender dan Hubungan Internasional [Gender and International Relations], edited by Ani Soetjipto and Pande Trimayuni, 167-193. Yogyakarta: Jalasutra.

\section{Journals}

Keohane, Robert O. 1989. "International Relations Theory: Contributions of a Feminist Standpoint." Millenium: Journal of International Studies 18(2):245-253.

Peterson, V. Spike. 1992. "Transgressing Boundaries: Theories of Knowledge, Gender and International Relations.” Millenium: Journal of International Studies 21(2):183-206.

Reus-Smit, Christian. 2012. "International Relations, Irrelevant? Don't Blame Theory." Millenium: Journal of International Studies 40(3):525-540.

Weber, Cynthia. 1994. "Good Girls, Little Girls, and Bad Girls: Male Paranoia in Robert Keohane's Critique of Feminist International Relations." Millenium: Journal of International Studies 23(2):337-349. 
Wibben, Annick T. R. 2004. "Feminist International Relations: Old Debates, New Directions." The Brown Journal of World Affairs X(2):97-114.

\section{Internet}

APEC CEO Summit. 2013. "Tony Fernandes: Government Connectivity is Important." Accessed 9 May 2017. http://www.apec2013ceosummit.com/coverage/tony-fernandesgovernment-connectivity-is-important.html.

Schmidt, Brian C. 2014. "The End of Great Debates?” accessed on December 10, 2017. www.e-ir.info/2014/02/02/the-end-of-great-debates/ 